\title{
State and Insurance The Long-Term Trends in Danish Health Policy from 1672 to 1973
}

\author{
Anne Løkke
}

\section{Introduction}

A Ithough health policy is only one part of welfare policy, it is a very distinguishing component of the Danish welfare system, with its massive state involvement: the state provides tax-financed, free medical care, free treatment in hospitals and sickness benefits for all permanent residents. Nearly all hospitals in Denmark are owned and run by the public, leaving only a minimal market for private hospitals and other forms of private medical care paid for by individual patients. In short, Danish health policy is characterised, as Esping-Andersen has described the Scandinavian welfare-state regime as a whole, by universalism and decommodification ${ }^{1}$ : the whole population receives services from the state, and the health services are not regulated by the market as commodities.

From abroad, this system is looked upon with dread or admiration, depending on political conviction, but also with wonder. How did it come into being and why do most Danes support it? And why is it not misused to a more serious degree?

What is not common knowledge is that this health system, which is seen by many, especially Americans, as "passive reliance on the state", was developed through enormous, voluntary civic engagement by non-profit health insurance societies (sygekasser). These associations were formed in the mid-nineteenth century and, starting in 1892, membership was encouraged by the state through substantial subsidies to those that accepted the advice, authorisation and auditing by the state. This policy succeeded, insuring an ever-increasing proportion of the population, such that by the mid-twentieth century almost the whole population was covered. 1990).

1 Gøsta Esping-Andersen, The Three Worlds of Welfare Capitalism (Oxford: Polity Press, 
It was not until the 1970s that the public took over the responsibilities of these civic health insurance societies.

In this paper, I am going to argue that the Danish health policy of today can not be understood separately from its history. The principles of universalism and decommodification have both developed through the civic health insurance societies. But the roots go farther back to experiences from nearly 200 years of absolutist, patriarchal biopolitics, including poor laws, educated, authorised and publicly-paid midwives, publicly-paid district surgeons etc. This system was continued unchanged, even after Denmark became a democracy in 1849. The absolutist poor laws and medical laws remained a frame of reference for all new welfare organisations well into the modern Danish welfare state of the 1960s. They defined a minimum threshold of medical and social security basically accepted by all classes in the society.

In an international context, the most interesting questions are, however, why this system was not dismantled by liberalism in the nineteenth century, like the Elizabethan poor laws in England or the civic health insurance societies of the US', and how this continuity has influenced the health of the Danish population and the economic growth of the society. Thus, this article will discuss the long-term trends in Danish health policy, with the greatest focus on the second half of the nineteenth century, presenting the preceding developments as context.

\section{Absolutist Health Policy}

From 1660 to 1849 , the Danish monarchy was an absolutist monarchy, a monarchy busily engaged in the competition between the emerging European states. This prompted huge biopolitical initiatives including medical laws, poor laws and school laws. The King's aim with the initiatives was surely to develop a great and healthy population able to provide taxes and soldiers. The aim was also to serve God by fulfilling the Royal duties of a good patriarchal master for the national household. Luckily for the Kings, the two aims were perfectly compatible, as care for the fatherless, poor and sick both pleased God and stimulated population growth. Just as learning to read and write did provide people with an instrument to improve their own economic situation, even though the purpose of education also was to prepare for the salvation of the soul.

The first medical law, of 1672, outlined the principles of an official health system for Denmark, which proved to be durable, lasting for more than 200 years. The law

2 Simon Szreter, Health, Economy, State and Society in Modern Britain: The Long-Run Perspective, Hygiea Internationalis vol 4:1 (2004), pp. 205-227. David Beito, From Mutual Aid to the Welfare State: Fraternal Societies and Social Services, 1890-1967, North Carolina. 2000. 
established a hierarchy with medical doctors on top, including barber surgeons, and authorised pharmacists and midwives as part of an official health care system. ${ }^{3}$ Although the 1672 law was visionary, economic realism guided the pace of its implementation. During the eighteenth century, public medical expenses were kept under control, but the innovations of this century included the establishment of a group of partly state-paid district surgeons, a Royal Lying-in Hospital (free of charge for poor unmarried women), a school for midwives, a medical hospital with free treatment for the able-bodied working poor and academy training for surgeons. $^{4}$

In the early nineteenth century, however, the health investments became massive. In 1803, the Royal Board of Health (Det kongelige Sundhedscollegium) was established as the supreme authority in public health administration. ${ }^{5}$ The number of district surgeons was enlarged. They were not only to be doctors of the poor, but were to be distributed all over the country to provide the whole population with access to a doctor and provide the state administration with yearly reports of health issues and warnings in case of epidemics. Their basic salaries were tax financed; they earned the rest as practitioners.

In 1810, a detailed regulation on midwifery was introduced with the purpose of reducing mortality among infants and mothers by ensuring that best practice in birth attendance was applied to all births, whether the mother was rich or poor. ${ }^{6}$ Every parish was required to appoint a district midwife who had been educated at the Royal School for Midwives and pay her a fixed, basic salary. In addition, her patients paid for each birth according to their income. The community paid for the poor. ${ }^{7}$ The district midwife was obliged to present herself unhesitatingly to every parturient woman who requested her help, and she was forbidden to leave a woman once labour had begun. It was explicitly mentioned that a midwife would be fined

3 Forordning om Medicis og Apotekere. 4 Dec. 1672. Cited from C. P. N. Petersen, Medicinallovgivning, vol. 1, (København, 1833).

4 For a more detailed presentation of the Danish medical system in the eighteenth and nineteenth century, see Anne Løkke, "the 'antiseptic' Transformation of Danish Midwives, 18601920", in Hilary Marland and Anne Marie Rafferty (eds.), Midwives, Society and Childbirth. Debates and Controversies in the modern Period (Routledge: london, 1997) pp. 103-112.

5 'Royal Ordinance of 13 May 1803', Cited from C. P. N. Petersen, Medicinallovgivning, vol. 1, (København, 1833).

6 'Regulation of 21 Nov. 1810', Petersen, Medicinallovgivning, vol. 2:1 (1834). For a more specific analysis of this aspect, see Anne Løkke, "The 'antiseptic' Transformation of Danish Midwives, 1860-1920", in Hilary Marland and Anne Marie Rafferty eds., Midwives, Society and Childbirth. Debates and controversies in the modern period (Routledge: London, 1997) pp. 102-133.

7 Anne Løkke, "Did Midwives matter 1787-1845". Pathways of the Past, Essays in Honour of Sølvi Sogner, (University of Oslo, 2002), pp. 59-72. 
severely if she left a poor patient to attend to a better off patient, because of the higher payment. ${ }^{8}$

The implementation of the law was remarkably quick. By around 1840, the public had completely adopted the system; every parish had an authorised, educated, relatively well-paid midwife and competition from unauthorised midwives had almost disappeared.' This was the birth attendance system Irvine Loudon has shown was among the most effective in the world until the 1940s, measured by its ability to keep mortality at a very low level for both mothers and infants. ${ }^{10}$

All the medical laws characteristically blurred the borders between the state and the private in several ways. The state provided the education, examination, authorisation, office structure and basic salary for doctors and midwives. In return they were expected to deliver services of the same high quality to all the King's subjects but only the very poor were to be served for free. The doctors and midwives were expected to charge their patients according to income, and in that way earn for themselves a decent living. Thereby the private interest of the doctor/midwife in a thriving practice and the interest of the state in an effective medical system were connected and the population grew used to the doctor or midwife being the same for all classes - doing their best in every case - and thereby separating quality from ability to pay.

Private practice outside the office structure of district medical officer/midwife was not prohibited, neither for doctors nor for midwives. On the contrary, it was encouraged, but outside Copenhagen, very few were able to make a living before 1850 as private practitioners without the basic wage for being district medical officers and midwives.

\section{Absolutist Poor Policy and School Policy}

Another huge investment of importance to health was the poor law from 1803. There had been ambitious poor laws in Denmark before, but they had depended on voluntary contributions and therefore very often faced shortages of means. The 1803 poor law secured the financial aspect by a principle mandating that local poor

8 Instructions of unknown date, but published in 1797. Continued in an almost identical 'Instruction of 3 May 1836'. F. A. Uldall, Haandbog $i$ den gjeldende civile MedicinaLovgivning, (Copenhagen, 1835), p. 43.

9 Det kongelige Sundhedscollegiums Forhandlinger for Aaret 1852, p. 258. J. Lehmann etc. eds. Hygiene and Demography, Denmark its medical Organization, presented to the seventh international congress of hygiene and demography London 1891, (Gjellerup, Copenhagen, 1891), p. 49.

10 Irvine Loudon, Death in Childbirth (Clarendon, Oxford, 1992). 
councils had the right and duty to support the local poor through local taxation, linking local democracy to tax-paying and social responsibility.

The Danish poor law did not distinguish itself in other ways from European poor laws: it was designed to be deterrent and scant, so nobody would be tempted to ask for it out of laziness. But it was to provide everyone in need with the bare necessities of life and medical treatment if sick, so that no subjects of the King would die from hunger, cold or treatable illness. Moreover, this law was soon accepted by the population as a lower limit for hardship, although the better off complained about the expenses and the poor dreaded the humiliation connected with receiving support.

The absolutist school policy must be mentioned as well, because the school laws of 1814 ensured that the majority of the population became literate before 1850, and thereby indirectly was a precondition for the later civic and deliberate organisation of health insurance. Quite a few of the common people had learned to read already in the seventeenth century, and the eighteenth century saw the establishment of numerous different schools, including many for children of peasants, artisans and workers. ${ }^{11}$ The 1814 school law, however, made it mandatory for children from seven to thirteen years of age to seek basal education in a school or in another way learn a specified minimum of religious knowledge, reading, writing, arithmetic, history and geography. The choice of school or teacher was the parents', but the local authorities were obliged to provide tax-financed schools, free of charge for every child whose parents did not prefer to or were not able to pay for schooling. ${ }^{12}$

\section{The Health Legislation and the Young Democracy}

When Denmark became a democracy in 1849, the medical laws, the poor law and the school laws had grown so familiar and legitimate that they were maintained almost unchanged. They constituted a known frame of reference defining a minimum threshold of medical, educational and economic security accepted by all classes in society. Additionally, the corps of civil servants of the state was kept by the new rule. Clergymen, jurists and doctors continued the biopolitic bureaucratic procedures of absolutism meant to preserve the life and health of individual subjects as a precondition for the prospering of the King and the country. Nobody thought of dismantling the tax-financed part of the support for educational and health personnel.

That does not mean, however, that there were no problems, discussions or political conflicts. On the contrary, the first 40 years of democracy was a period

11 Charlotte Appel, Læsning og bogmarked i 1600-tallets Danmark (Copenhagen, 2001).

12 Joakim Larsen, Skolelovene af 1814 (Copenhagen, 1914). 
with very fierce political discussions about these matters. However, removing or reducing the level of medical and economic security was not considered. What was discussed, however, was how the basic security could be conserved or even improved, without inviting misuse, laziness or resignation, without expenses growing wildly and without hampering economic growth. ${ }^{13}$

The fathers of the new constitution not only accepted the poor law, but included it as an inalienable right to be provided for by the public if one was unable to do so oneself. But at the same time loss of the franchise was added to the stigmatising consequences of receiving poor relief. And many parishes started to build workhouses, where poor relief receivers were forced to live as a precondition for help. Both procedures were meant to deter people who were not in the most desperate need from asking for poor relief. But nevertheless, the new democracy accepted the responsibility of taking care of the very poor in an economic situation in which most of the working population could only afford a very simple living and often less than that. ${ }^{14}$

The 1850 s and 1860 s were dominated by national-liberal politicians, the majority of whom trusted liberalism as the road to economic growth. However, what they understood as liberalism was not wild capitalism, but the removal of old privileges and monopolies that prevented competition in trade and production. When a freedom of trade law was passed in 1857, which dissolved the guild system, it was broadly believed that the economic growth that was expected as a result automatically would solve the problems of poverty for the working class. The obstacles preventing the workers from engaging in voluntary, independent self-help organisations to provide health insurance and old age pensions would be removed as well. In reality, a lot of organising of this kind took place. ${ }^{15}$ Numerous private citizens engaged in local attempts to build workers' self-help organisations and many workers engaged in them too, but very few associations were able to deliver real, social security to the members in cases of sickness and old age.

The 1870s saw a shift in the agenda: the socialist labour movement, which was germinating in Copenhagen, claimed revolution to be the only solution to the misery of the workers. The strength of the movement, apparent from its ability to organise strikes, scared authorities and middle class citizens alike. This stimulated a sudden joint interest from liberals and conservatives to determine whether the workers really lived in unmerited misery, preventing them from organising their own insurance to guard them in cases of sickness and old age. Thus started a politi-

13 Anne Løkke, “Tryghed og risiko. Forsikring 1850-1950”, In Ole Feldbæk ed., Drømme om Tryghed, Forthcoming (Gads Forlag: Copenhagen, 2007).

14 Jacob Christensen, De fattige 1814-1848 og Socialforvaltningen 1848-1901, in Tim Knudsen, Dansk Forvaltningshistorie, I, (Akademisk Forlag: Copenhagen, 2000).

15 Anne Løkke, “Tryghed og risiko. Forsikring 1850-1950”, In Ole Feldbæk ed., Drømme om tryghed, forthcoming (Gads Forlag: Copenhagen, 2007). 
cal and scientific process lasting twenty years, leading to the first social laws in the 1890 s, carried through by a conservative government. ${ }^{16}$

\section{The Economic and Health Consequences of the Poor Law in Nineteenth Century Denmark}

According to censuses, the percentage of the population living permanently on poor relief was relatively stable at $2-3 \%$ in the years $1850-1880 .{ }^{17}$ About twice as many got temporary relief every year, which is not reflected in the censuses. Neither did anybody in the past collect central data in other ways about this issue; only the local poor relief authorities knew how much was spent. In Copenhagen in 1878, for example, $4 \%$ of the inhabitants of Copenhagen succumbed to temporary poor relief because of sickness and $9 \%$ had expenses for medical care or hospitalisation paid for by the poor-law authorities during that year. ${ }^{18}$

The poor relief was given whatever the cause of need, but some groups were more at risk of becoming needy than were others. A study done in connection with the 1880-census revealed that, in the rural districts, children, women and old people made up the majority of the receivers. (Figure 1)

The number of children from birth to 5 years of age was not included in this study. If, however, their number is estimated to be the same as the number of children 5-10 years old, the distribution among the poor relief receivers was approximately: $35 \%$ children younger than 15 years of age, $2 \%$ young people (15-25 years of age), $21 \%$ adults (25- 55 years of age) and $41 \%$ elderly (older than 55 years of age). The majority of the adult women receiving poor relief were single mothers or widows with responsibility for children. This study showed that $8 \%$ of the elderly male population (older than 65 years of age) received permanent poor relief. Of the elderly female population it was $13 \%$. Among elderly agricultural workers, more than a fourth were poor relief receivers after the age of 55 years. ${ }^{19}$ A study of the poor relief receivers during most of the nineteenth century shows the same picture: orphaned children, single mothers, the sick and elderly, who could by no means provide for themselves in other ways and who lacked other social relations

16 An analysis of this process can be found in Anne Løkke, "Creating the social question. Imagining society in statistics and political economy in late nineteenth century Denmark", Histoire sociale/Social History. vol. XXXV, no. 70 (2002), pp. 393-422.

17 Calculated from Statitisk Tabelvark A, V, Copenhagen 1905, table 39 and 120.

18 Calculated from Tabelvark til Kjøbenhavns Statistik Nr. 4, 1879, pp. 85, 129 and 132133 and Statistisk Tabelvark 5 R. Lt. A, Nr. 5, 1905 table 9.

19 Marcus Rubin og Harald Westergaard, Landbefolkningens Dødelighed i Fyens Stift, (Copenhagen 1882), pp. 26-27. 
Figure 1. Poor relief receivers in agricultural districts. Fyn 1880-census.

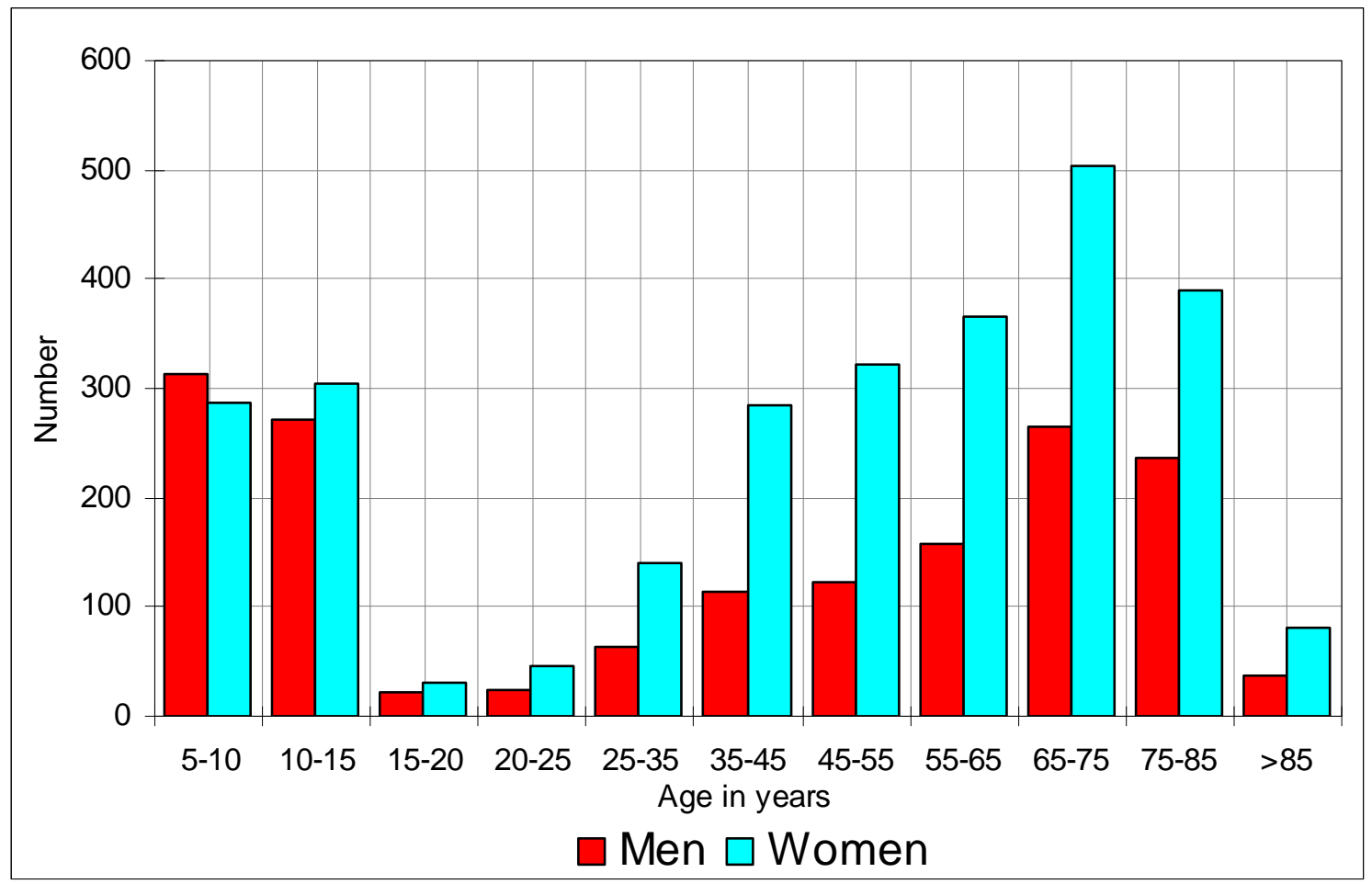

able to provide for them, were the ones who got the poor relief. ${ }^{20}$ This distribution of the poor relief receivers suggests that the social security provided by the poor law, however scant, was of great importance for the life and health of the most vulnerable. These people would have succumbed to the elements and starvation if left to themselves.

During the nineteenth century, Denmark experienced very rapid population growth: from 1800 to 1900 the growth was $164 \%$. That is among the highest in Europe. The rapid growth continued until the 1920s, when a decline in the growth rate began. In absolute numbers, the population increased from roughly one million in 1801 to two million in 1880 and four in $1940 .^{21}$ Infant mortality was amongst the lowest in Europe. ${ }^{22}$

Thus, Malthus may have been right in suspecting that poor laws stimulated population growth. Both the many children provided for and the old people escaping death from starvation must have contributed to this rapid growth. But instead of being a problem, the population growth in Denmark seems to support the argument proposed by Simon Szreter. He suggested that, far from being an obstacle to the industrial revolution and economic growth in Britain, the poor laws

20 Tabelværk til Kjøbenhavns Statistik Nr. 4, (Copenhagen, 1879).

21 Statistisk Tabelvark 5 R. Lt. A, Nr. 5 (Copenhagen, 1905).

22 Anne Løkke, Døden i Barndommen, (Gyldendal: Copenhagen 1998), p. 120. 
were an important precondition for both. ${ }^{23}$ In Denmark, the industrialisation took place slower and later than it did in Britain, and was a fairly continuous process. It is therefore not very meaningful to speak about an industrial revolution; no single period experienced a very rapid change of everything. Rather, a series of industrial growth periods took place starting in the late eighteenth century, when the first tiny textile industry was established. Small iron foundries popped up throughout the country from the 1840 s and the early 1870s. The 1890 s included periods of more rapid industrialization as well. ${ }^{24}$ The industrial, manufacturing and construction proportion of the Gross National Product was $20 \%$ in the 1870 s, $27 \%$ in the late 1890 s and $39 \%$ in $1960 .^{25}$

At the same time, agriculture was a very important sector in the economic growth. Starting in the late eighteenth century, waves of massive capital investments, new technology, new methods of cultivation and changes in products have taken place within agriculture, resulting in increasing productivity and economic growth inside the agricultural sector. This development in agriculture went hand in hand with increasing manufacturing, commerce and investments in the infrastructure. Together the result was considerable economic growth throughout the nineteenth and twentieth centuries. ${ }^{26}$ The Gross Domestic Product at Factor Cost rose $2 \%$ p.a. (0.9\% p.a. per capita) in the period $1822-1894$. In the period $1894-1914$, the rise increased to $3.5 \%$ p.a. $\left(2.2 \%\right.$ per capita p.a.). ${ }^{27}$ The proportion of the population living in urban areas increased from $20 \%$ in 1801 to $38 \%$ in 1901 , reaching $47 \%$ in $1960 .^{28}$

My argument, following Szreter's, is that the Danish case indicates that the poor law and the more generous social laws of the 1890s did not prevent industrialisation and economic growth. On the contrary, it was a precondition for the economic growth that the population growth provided new hands ready for both agriculture and industry whenever the demand for labour increased.

23 Simon Szreter, Health, Economy, State and Society in Modern Britain: The Long-Run Perspective., Hygieja Internationalis vol 4:1 (2004), pp. 205-227.

24 Ole Hyldtoft, Københavns industrialisering 1840-1914, (Summary in English), (Systime: Herning, 1884), pp. 418-428.

25 Svend Aage Hansen, Økonomisk Vakst i Danmark, vol 2, (Gads Forlag: Copenhagen, 1972), pp 209-220. 1972).

26 Svend Aage Hansen, Økonomisk Vakst i Danmark, vol 2, (Gads Forlag: Copenhagen,

27 Svend Aage Hansen, Økonomisk Vakst i Danmark, vol 2, (Gads Forlag: Copenhagen, 1972), p. 18.

28 Statistisk Tabelvark 5 R. Lt. A, Nr. 5, Copenhagen 1905, pp. 9-16; H. C. Johansen, Dansk Økonomisk Statistik, in Søren Mørch etc. (ed.), Danmarks Historie vol. 9 (Copenhagen, 1885), p. 22. 


\section{The Social Laws of the 1890s}

The social era of Danish welfare policy started in the 1890s. The economic growth made it possible to increase expenses, and the new political strength of the workers' movement prompted a new attentiveness from the government and civil servants to the standard of living of the working population. Among the civil servants, the old perspective of the absolute monarchy trying to promote what was good for society as a whole was still alive. They argued for a policy that would avoid the type of disruptive situation seen in England under the most rapid industrialisation and urbanisation.

An old-age-pension law was passed in 1891, simply meant to exempt the working poor from the stigmatising aspects of poor relief in old age, if they had been able to care for themselves until the age of $60 .^{29}$

The health insurance law of 1892 was more ambitious and built upon a more dynamic and structural understanding of poverty, than did both the poor law and the old-age-pension law. The health insurance law was meant to prevent the rise of poverty by curbing the negative spiral, which so often started with a provider falling ill in families with such small reserves that within a few days the choice was between hunger and poor relief. As even temporary poor help triggered the full stigmata of the poor law, many proud workers waited too long from a health point of view to ask for relief. The health insurance law was thought of as a way to keep up future economic growth by securing the future work capacity of individuals, by providing the best conditions for recovery. The means chosen was to give the honourable worker access to some compensation for lost wages and free medical care without the slightest doubt that it was a paid-for right and not poor relief. Therefore, it was given in the form of insurance with a member's fee. In fact, the organisation as insurance was used to mask a considerable amount of state subsidies.

The Danish health insurance law was designed in deliberate, proud opposition to what was called the German coercion law, which ordered mandatory health insurance for workers primarily in industry, partly paid for by the employer. ${ }^{30}$ The Danish law was built on voluntary membership of local, self-organised societies. Since the 1860s, there had been an increasing interest in establishing such societies, alongside cattle insurance associations, personal property fire insurance associations, burial clubs and other voluntary, locally organised societies providing economic security on a mutual insurance basis. In 1885 there were 986 medical-aid societies, many of which, however, struggled severely to provide the help the members

29 Lov om alderdomsunderstøttelse til værdige Trængende udenfor Fattigvæsenet, 1891, Lovtidende.

30 Betenkning afgiven af den af Indenrigsministeriet d. 4. Juli 1885 til Overvejelse af Spørgsmaalene om Sygekassernes ordning og om Arbejdernes Sikring imod Folgerne af Ulykkestilfalde under Arbejdet nedsatte Kommission (Copenhagen, 1885) p. 23. 
needed using the fees they were able to pay. The law opted to close that gap. It stated that if a society, which exclusively admitted members who did not earn more than a skilled worker, accepted being advised, authorized and getting its accounts audited by the state, it would receive state subsidies to supplement the members' fees. The society in return would provide a minimum sick benefit per day, free medical care and hospital treatment to the members.

To administrate the aid given to and the control of the societies, a new government office was created. A medically, statistically and politically experienced doctor, Th. Sørensen, was appointed its first chief. The choice of a medical doctor was not simply by chance. As in the US, many Danish doctors were against collective contracts with the health insurance societies. The Danish (conservative) government considered this resistance to be intolerable for the well-being of society as a whole; farmers party saw it as greedy urban arrogance and social democrats found it to be a threat against the health and lives of the workers. Political consensus was the background for choosing Th. Sørensen; he had the capacity to take care of the implementation of the law. In the first years it took all his skills in organising, explaining and negotiating to attract the old societies to the deal, to set up new societies where they were missing and to settle conflicts between doctors and societies. Backed by the authority of the state and the political system, he was able to end the doctors' resistance and propagate their understanding that the higher the percentage of the working population in insurance societies, the more these people would be able to seek medical treatment. ${ }^{31}$ Time would show that he was right. The number of doctors increased from 676 in 1871 and 970 in 1890 to 1,918 in 1920 and 3,332 in 1940 , corresponding to 1 doctor per 4,055 inhabitants in 1871 to 1 doctor per 1,153 inhabitants in $1940 .^{32}$

The societies were able to keep the administration expenses at a very low level, because the members did the administration themselves as an un-paid, spare-time occupation or as part-time work paid the same wage per hour as the members normally got in their occupations. A precondition for this was that the school laws had given the worker population access to enough skills in writing and arithmetic to manage the accounts and the necessary bureaucracy. In that way, the health insurance societies - as with the hundreds of other self-organised insurance associations in nineteenth and early twentieth century Denmark - invested in the intelligent reserve of workers and farmers in the establishment of economic stability for the whole of the working population.

31 Anne Løkke, “Tryghed og risiko. Forsikring 1850-1950”, In Ole Feldbæk ed., Drømme om Tryghed, Forthcoming (Gads Forlag: Copenhagen, 2007).

32 Falbe-Hansen and Scharling, Danmarks Statistik vol V (Copenhagen, 1881), pp. 80-82, Statistiske Undersøgelser nr. 19 (Copenhagen, 1966) p. 165. 
Further, fraud control was carried out inexpensively. As the members were neighbours or fellow workers or both, local informal social control mechanisms were effective concerning fraud control, without extra expenses.

Within a few years, the law succeeded in having a large proportion of the working population covered by health insurance. The target group (the people not earning more than a skilled worker) made up $75-80 \%$ of the population. Disabled people and people who for other reasons were unable to earn a living were not admitted. Thus, 62.6\% (Table 1) of the population were members in 1930, which was very high coverage for a voluntary health insurance.

Table 1: Members of health insurance societies per 100 inhabitants more than 14 years of age, Denmark 1901-1950.

\begin{tabular}{|c|c|c|c|c|c|c|c|}
\hline & & 1901 & 1911 & 1921 & 1930 & 1940 & 1950 \\
\hline \multirow{3}{*}{$\begin{array}{l}\text { Entitled } \\
\text { to state } \\
\text { subsidy }\end{array}$} & Men & - & 38.1 & 61.5 & 61.5 & 73.6 & 73.4 \\
\hline & Women & - & 37.5 & 63.6 & 63.6 & 75.9 & 76.5 \\
\hline & Total & 20.0 & 37.8 & 57.4 & 62.6 & 74.8 & 75.0 \\
\hline \multirow{2}{*}{$\begin{array}{l}\text { Not } \\
\text { entitled } \\
\text { to state } \\
\text { subsidy }\end{array}$} & $\begin{array}{l}\text { Stand-by } \\
\text { members }\end{array}$ & & - & - & - & 9.7 & 8.3 \\
\hline & $\begin{array}{l}\text { Private } \\
\text { health } \\
\text { insured }\end{array}$ & & - & - & - & - & 9.9 \\
\hline $\begin{array}{l}\text { Total } \\
\text { health } \\
\text { insured }\end{array}$ & & - & - & - & - & - & 93.2 \\
\hline
\end{tabular}

Source: Statistisk Aarbog 1902, 1912, 1922, 1932, 1942 and 1952. Statistiske Undersøgelser nr. 19 (1966), pp. 26-27.

In 1933 the system was reformed; membership in a health insurance society became mandatory for every non-disabled citizen more than 21 years of age, regardless of income, but still the wealthier people did not receive state subsidy. They could choose to fulfil the insurance requirement with a very inexpensive Stand By membership by waiving the right to immediate coverage. The point was that a Stand By membership could easily be turned into an active membership after a deferred period. This prevented total social de route for middle class people facing unexpected hardship. Or they could choose membership in a health insurance society only taking members from among wealthier people. Commercial private health insurance had been offered during these years by different insurance companies, but they all gave up, as they tended to attract only customers who tried to avoid the close social control in the societies.

33 J. Langkilde Larsen ed., Håndbog i forsikring vol 1, Copenhagen, pp. 388-389. 


\section{Individual Membership for Women}

The most important reason for the high level of coverage in Denmark was that women were treated as individuals entitled to their own membership and the societies were free to design their insurance products so they suited various member groups including women and rural labourers (Figures 2, 3 and 4). The working poor, especially from the countryside, were attracted to societies providing the minimum coverage for a low fee. The male skilled workers in Copenhagen made themselves more covering, but also more expensive insurances. But the law prescribed that the difference was only in the size of the pay received per day under sick-leave. All societies had to pay for doctors, midwives, hospital stays and in some cases medicine.

Figure 2. Sickness benefit Copenhagen 1898. Health insurance associations with this per diem sickness benefit in percent of the total number of health insurance associations in Copenhagen.

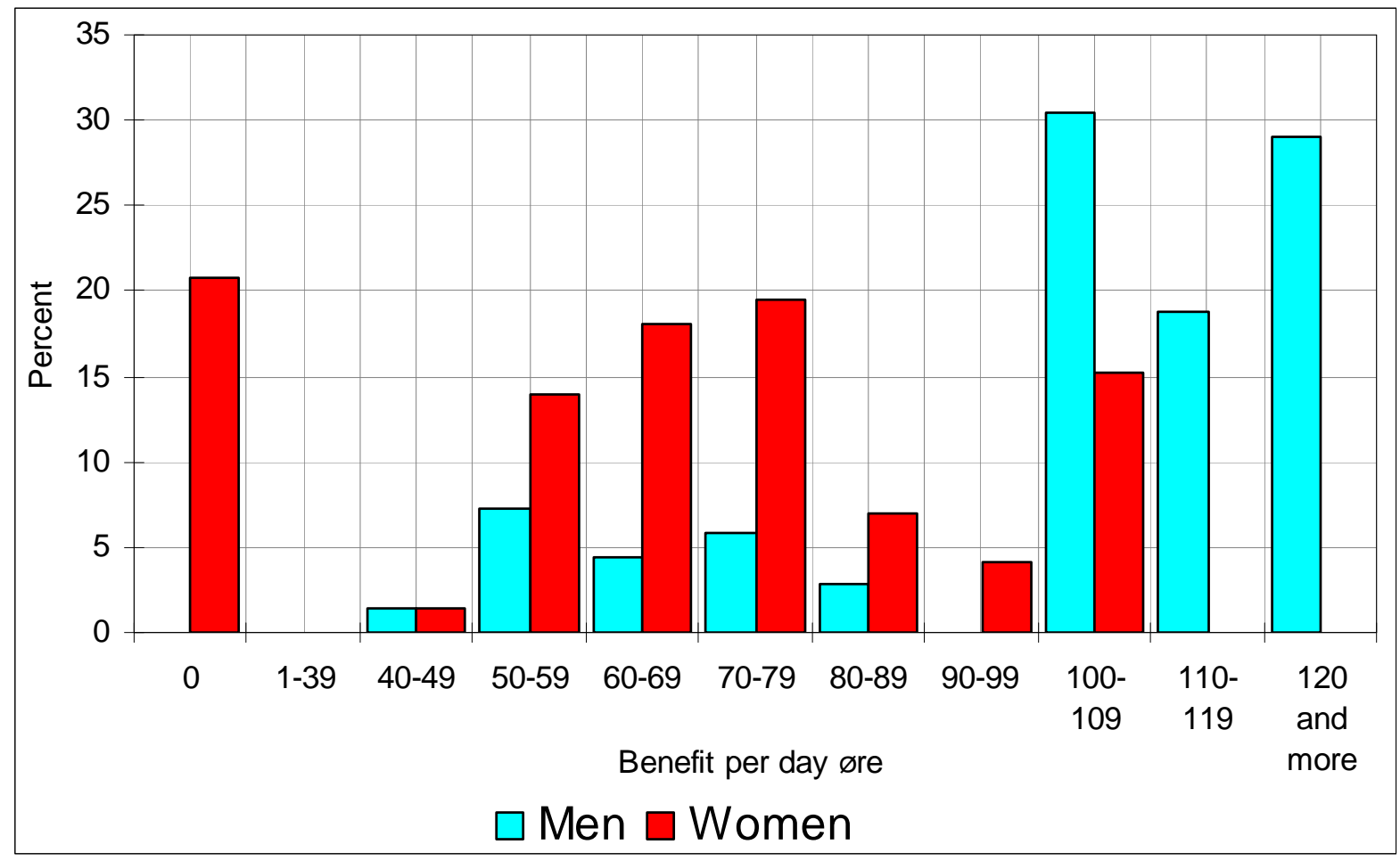

Individual membership instead of family membership was a last minute decision before the law was passed, following the pattern of the existing Social Democratic health insurance societies. The commission preparing the law, as a matter of course, had proposed that a husband's membership should include his wife. The final law decreed instead that the societies should offer women individual membership at a discount price if they would only be receiving medical attendance and medicine and not a per diem sick benefit. Women were in no way denied the more expensive memberships with per diem benefits included, but many chose the cheapest 
Figure 3. Sickness benefit per day from health insurance societies for men 1898 . Health insurance associations with this per diem sickness benefit in percent of the total number of health insurance associations in this geographical setting.

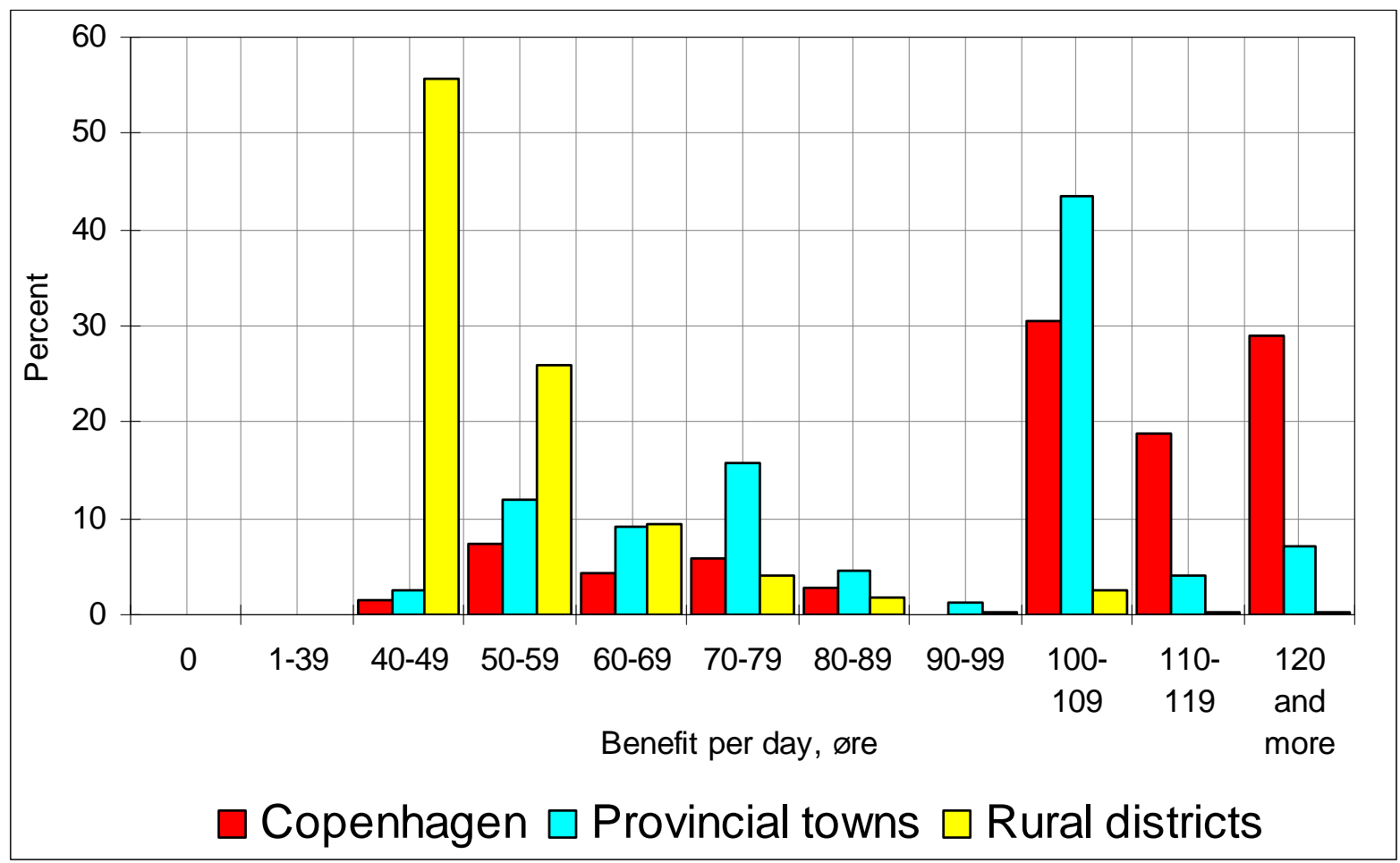

Figure 4. Sickness benefit per day from health insurance societies for women 1898. Health insurance associations with this per diem sickness benefit in percent of the total number of health insurance associations in this geographical setting.

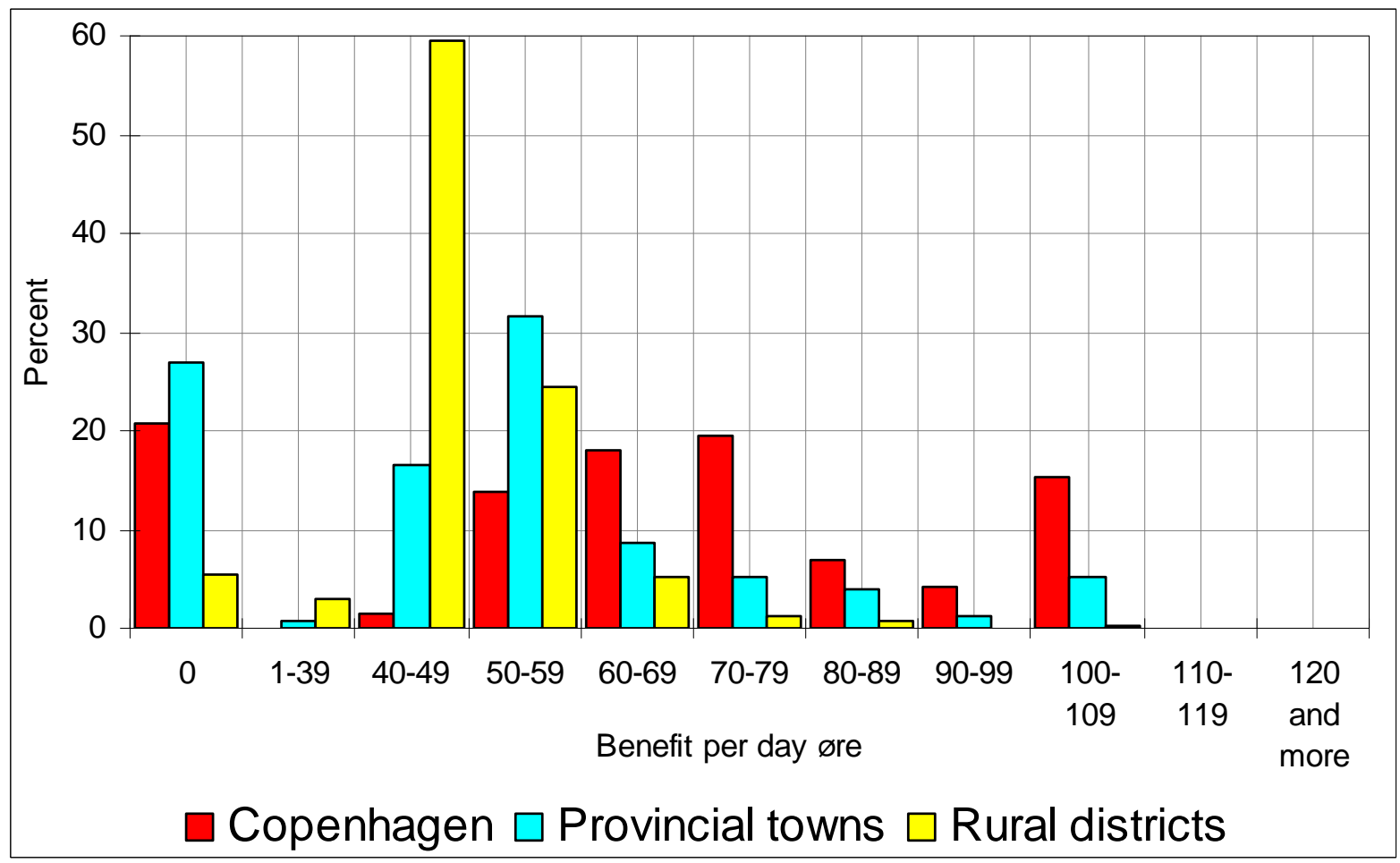


solution. Of course this was reflecting as well the power hierarchies in the families, the often non-registered status of the occupation of married women and the huge gap in pay between the sexes. Generally, women earned approximately $40 \%$ of the pay men earned, making a full membership in a health insurance society unattainable. Although the law reflected the inequality of women, it nevertheless provided them with the possibility of having their own membership not dependent on their husbands' workplace, as in Germany, or on their marital status as first proposed in Denmark, which was a useful position in the long run.

Children were automatically covered both by the fathers' and the mothers' memberships.

\section{The Small Step to Tax-Financed State Insurance}

In 1973, the system with independent, state-subsidised health insurance societies was abandoned and their engagements taken over directly by the state. Every inhabitant in Denmark was now automatically health insured, financed by taxes and administrated by the public county and local administration. It was not a Social Democratic government that carried this reform out. On the contrary, it was a coalition government consisting of the three most rightist parties (the liberals, the conservatives and the radical liberals) - with a liberal Minister of Social Affairs. It was passed, however, in parliament with nearly complete consensus. Nobody voted against it - only 10 members (out of 179) abstained from voting. ${ }^{34}$

My argument is that the unanimous passing of a law that made it a responsibility of the state to provide every citizen from cradle to grave with high quality medical aid and economic security in case of sickness was possible only because it was experienced as a relatively small step, logically following the health policy maintained by changing democratic governments and the absolutist monarchy for several hundred years.

\section{Discussion and Conclusions}

When following the long-term trends in Danish health policy, the path dependency becomes very obvious. The decommodification and the universalism, so characteristic of Scandinavian Social Democratic welfare regimes, was not invented overnight and was not carried through by social democrats in fierce opposition to liberal and conservative parties. On the contrary, the laws taking the most decisive steps

34 H. C. Hansen, Historien om Sygekasserne, (Schølins bogtrykkeri: Aalborg ,1974), pp. $238-241$. 
towards these principles were all passed by conservative or liberal governments or by the absolutist King. Every crossroad offered several possibilities for solutions to the actual health policy problems, but no government dared to choose the road that provided a less efficient health policy for the population than the existing one. The barrier, among others things, being that there were civil servants, whose professional responsibility was to improve the long-term health of the whole population. The fierce body of tax-funded civil servants - clergymen, judges, doctors et cetera were trained to take care of society as a whole, and did in fact make a fair match for the private interests of professional groups, like doctors, and business interests, like insurance companies.

Chance timing was also of importance here. There was a close connection between the central perspective of the absolute King and the central perspective of the social democrats once they settled on reform instead of revolution. The very few years that passed from the abolishment of the absolutist monarchy in 1848 to the emergence of the social democrats in the 1870s implies that the paternalistic sense of responsibility from the time of absolutism was alive among the conservative civil servants until the new ideology of social responsibility emerged among the social democrats.

The decommodification of medical aid reaches back to the laws of district surgeons and midwives from the years around 1800, which saw it as a goal to provide the whole population with the same high quality attendance for the price everyone was able to pay. In the case of birth attendance, this was implemented successfully as early as the 1840s. As regards service from doctors and hospitals, the health insurance act of 1892 meant that nobody should be inhibited from the medical treatment recommended at the time due to economic reasons. Although it can be argued with consistency that the wealthier still had (and have) the economical, social and cultural capital to obtain better than average treatment, it was (and is) very much against the national self-perception to declare that inequality in the access to medical aid is a natural consequence of economic inequality. The population has grown too used to the patriarchal biopolicy trying to distribute best practice to everyone to support any political party that would want to cancel that.

The universalism component of the Scandinavian welfare regime concerning health policy has taken a more meandering path, as it began as voluntary insurance. What distinguished it from the start in comparison with the liberal welfare stateregimes was that the population could be assigned to one of three categories, instead of two, in relation to state subsidies for medical treatment and sickness benefit: 1) The destitute receiving dishonourable poor relief, 2) the honourable working population, who entered a state subsidised health insurance society and 3) the well off, who could pay for themselves or enter a non-subsidised insurance society. The important thing was that the social laws distinguished the honourable workers from both the paupers and the well-to-do. In the early twentieth century, 
$75-80 \%$ of the population, according to these categories, belonged to the honourable workers entitled to be members of the subsidised health insurance societies, $20-23 \%$ were better off. A very small percentage, which decreased with every new social law, were paupers obliged to poor relief. The 1933 act included everyone in the same system, although the wealthier still paid for themselves. The step towards universalism thereby was only minor compared to states in which public medical aid and sick benefits still are handled as a kind of poor relief.

The history of the Danish welfare state can be explained with economic growth as an independent precondition. The absolutist Kings as well as the democratic fathers of the social laws of the 1890s, however, were very aware of the damage done by poor social security in cases of illness: the undesirable effects on the national economy of letting citizens become destitute was by no means hidden for them and historical analysis shows that organisations providing economic security and better medical treatment served more as accelerators of economic growth than as hindrances in the Danish case.

Of course there are weaknesses as well as strengths in the Danish tax-paid health system of today, as is the case with all health systems. One problem is how to tackle the freedom of individuals who choose health-threatening lifestyles when everybody else has to pay their medical bill through their taxes. Another problem is how to develop and distribute different high quality treatments meeting the needs of different people, when health services are not commodities in a market. An important strength is that over treatment of the rich and under treatment of the poor is not a problem.

Overall, however, the most important strength is that the very existence of more than one organisation of health systems provides the world with the opportunity to compare. Combined with reliable health statistics exposing the results of different systems, it provides an opportunity to learn from each other and thereby improving the performance in the different systems.

Anne Løkke, $\mathrm{PhD}$, is an Associate Professor at the Department of History, SaxoInstituttet, University of Copenhagen, Copenhagen, Denmark. Mail address: al@hum.ku.dk.

\section{Acknowledgement}

The research for this paper is derived from a project I am engaged in, entitled "Safety and risk - the principle of insurance in Denmark". A book (in Danish) is under publication, expected spring 2007. The book examines all types of economic security organisation and risk management for individuals, where the principle of insurance has been used - whether it has been organised by the state, by associa- 
tions or by companies. A previous version of this paper was presented at the PHOENIX network meeting at Catania 2005, and printed in a volume following the meeting. I want to thank the participants for comments and discussions. The English writing in this paper was corrected by Deborah Licht. 